Article

\title{
No Strong Leaders Needed? AfD Party Organisation Between Collective Leadership, Internal Democracy, and "Movement-Party" Strategy
}

\author{
Anna-Sophie Heinze ${ }^{1}$ and Manès Weisskircher ${ }^{2,3, *}$ \\ ${ }^{1}$ Trier Institute for Democracy and Party Research (TIDUP), Faculty of Political Science, University of Trier, Germany; \\ E-Mail: heinzea@uni-trier.de \\ ${ }^{2}$ Department of Sociology and Human Geography, University of Oslo, Norway; E-Mail: manes.weisskircher@sosgeo.uio.no \\ ${ }^{3}$ Center for Research on Extremism (C-REX), University of Oslo, Norway \\ * Corresponding author
}

Submitted: 17 May 2021 | Accepted: 17 August 2021 | Published: 24 November 2021

\begin{abstract}
This article analyses the formal and lived organisation of the Alternative für Deutschland (AfD, Alternative for Germany). We show that the party is exceptional among what is usually understood as the populist radical right (PRR) party family, at least from an organisational perspective: The AfD sharply contradicts the "standard model" of PRR party organisation, which emphasises "charismatic" leadership and the centralisation of power as key features. Instead, studying the AfD's efforts to adopt some elements of a mass-party organisation and its relatively decentralised decision-making underlines the importance of "movement-party" strategy, collective leadership, and internal democracy-concepts that are usually associated with Green and left-wing parties. Our analysis shows how the party's organisation is essential for understanding its development more broadly as it reflects and reinforces sharp intra-party conflict. From this perspective, the case of the AfD sheds new light on the relationship between PRR party organisation and electoral success, indicating the importance of strong ties to parts of society over effective internal management as long as demand for anti-immigration parties is high. We conclude that even though AfD quickly built up a relatively inclusive organisational structure, the role of both its leadership and its rank-and-file is still a matter of controversy.
\end{abstract}

\section{Keywords}

AfD; intra-party democracy; leadership; movement-party; party organisation; populism; radical right

Issue

This article is part of the issue "Right-Wing Populist Party Organisation Across Europe: The Survival of the Mass-Party?" edited by Daniele Albertazzi (University of Surrey, UK) and Stijn van Kessel (Queen Mary University of London, UK).

(C) 2021 by the authors; licensee Cogitatio (Lisbon, Portugal). This article is licensed under a Creative Commons Attribution 4.0 International License (CC BY).

\section{Introduction}

This article analyses the formal and lived organisation of the Alternative für Deutschland (AfD, Alternative for Germany). Since its foundation in 2013, the party has received ample academic attention. Still, despite the party-centrism of political science, the AfD's internal organisation has largely been neglected (e.g., in the otherwise comprehensive volumes by Häusler, 2016; see also Schroeder \& Wessels, 2019). In line with the goals of this thematic issue (Albertazzi \& van Kessel, 2021), our article investigates the extent to which the AfD has adopted a mass party-type organisation, defined by "the drive to recruit a large activist membership," "rootedness on the ground and the provision of a variety of activities to members," and "the preservation of collective identities through ideology." In addition, it will reflect on the extent to which the party decentralised its decision-making procedures.

We show that the AfD is exceptional among what is usually understood as the populist radical right (PRR) party family, at least from an organisational perspective, 
as it sharply contradicts the "standard model" of PRR party organisation, which emphasises "charismatic" leadership and the centralisation of power as key features (Betz, 1998; Heinisch \& Mazzoleni, 2016). Instead, studying the AfD's efforts to adopt some elements of a mass-party organisation and its relatively decentralised decision-making underlines the importance of "movement-party" strategy, collective leadership, and internal democracy-concepts that are usually associated with Green and left-wing parties (della Porta et al., 2017; Rüdig \& Sajuria, 2020; Sanches et al., 2018). We call for a renewed focus on these dimensions, not only because these concepts have received too little attention in the study of the PRR (with only movement-parties receiving some consideration; see Caiani \& Císař, 2019; Pirro \& Castelli Gattinara, 2018), but also because they have remained important omissions in recent research on party organisation more generally (e.g., Scarrow et al., 2017; but see also Kitschelt, 2006; Martin et al., 2020).

Our analysis of the AfD shows how its organisation is essential for understanding the party's development more broadly as it reflects and reinforces sharp intraparty conflict. The absence of a charismatic leader and the lack of strong centralisation indicates that no single faction has managed to dominate the party. Moreover, the absence of strong leadership has provided plenty of opportunities for the public expression of internal disagreement. From this perspective, the case of the AfD sheds new light on the relationship between PRR party organisation and electoral success, indicating the importance of strong ties to parts of society (Dinas et al., 2016) over effective internal management (Art, 2011; Bolleyer \& Bytzek, 2017; Carter, 2005) as long as demand for antiimmigration parties is high.

Methodologically, the AfD constitutes a "least-likely case" (e.g., Bennett \& Elman, 2006, p. 462) of an inclusive party organisation, i.e., it focuses on mass recruitment and relies on decentralisation of power despite its party family membership. For this study, we draw on numerous sources: AfD statutes and other official documents and publications, party communication (e.g., websites of federal and state branches, social media channels, AfD media productions), data on AfD members and their regional distribution, as well as media articles.

The next section provides an overview of the history of the AfD, highlighting its stark internal conflicts and its significant electoral success. After that, we analyse the AfD's formal and informal organisation, underlining the party's adoption of some elements of a mass-party organisation, not only due to significant membership but also its outreach to far-right social movement groups, subcultural milieus, and the online sphere. We then discuss to what extent power is decentralised within the AfD and how its instruments of internal democracy operate in practice. In the conclusion, we stress the need for further research on the practices and perceptions of intra-party democracy within PRR parties and their relationship towards social movements.

\section{A Brief History of the AfD: Internal Conflict and Electoral Success}

For a long time, Germany was known for lacking an established party right of the centre-right. Parties such as Nationaldemokratische Partei Deutschlands (NPD, National Democratic Party), Die Republikaner (REP, The Republicans), and Deutsche Volksunion (DVU, German People's Union) failed to break through (Backes \& Mudde, 2000; Decker, 2000). Therefore, the AfD counts among the youngest electorally successful PRR parties in Europe. So far, its history has been shaped by considerable electoral support despite stark internal conflict (for an overview see Arzheimer, 2019).

Party foundation in early 2013 was primarily initiated by neoliberal economists, former low-profile members of Christlich Demokratische Union Deutschlands (CDU, Christian Democratic Union of Germany) and Freie Demokratische Partei (FDP, Free Democratic Party), and Christian-conservative activists. It was a response to the German government's Eurozone policies, which chancellor Angela Merkel described as being "without alternative," and reflected the long-term dissatisfaction with the CDU's "shift to the left" among parts of Germany's organised (centre-)right, dating back to the 1990s (Biebricher, 2018). In September 2013, only a few months after its foundation, the AfD narrowly failed to pass the five percent threshold in the federal election (4.7 percent) and the state election in Hesse (4.1 percent). After this reasonably strong showing, the party entered the European Parliament in 2014, gaining 7.1 percent. Since then, the AfD not only managed to enter all state legislatures but also became Germany's third-strongest party when it eventually entered the Bundestag in 2017 (12.6 percent; see Heinze, 2020b). In 2021, the AfD re-entered parliament with 10.3 percent, losing some of its support ( -2.3 percent) and its position as strongest opposition party. Importantly, the party's stronghold has been eastern Germany, the former territory of the German Democratic Republic, where it is about twice as strong as in the west, regularly attracting over 20 percent of the vote (Weisskircher, 2020b). In the 2017 federal election, the AfD was the most popular party in the eastern state of Saxony. Four years later, it attracted the highest number of votes in both Saxony and Thuringia.

So far, deep internal divides have not hampered the party's success at the ballots. In its early days, the AfD was not yet described as populist or even radical right, but essentially constituted a neoliberal party (Arzheimer, 2015; Berbuir et al., 2015). However, PRR forces quickly made a name for themselves, especially in AfD's eastern state branches. Their growing strength was indicated by the rise of groups such as the Patriotische Plattform (Patriotic Platform) in 2014 and the publication of documents such as the 2015 Erfurter Resolution, which portrayed the party as a "resistance movement against the further erosion of Germany's sovereignty and identity" (Höcke \& Poggenburg, 2015, p. 1). The party conference 
in Essen in July 2015, even before the intensification of the "refugee crisis" in Europe, finally marked the AfD's turn to the PRR: AfD Saxon leader Frauke Petry was elected co-spokesperson, replacing co-founder Bernd Lucke, who left the party together with about 2,000 to 3,000 rather moderate members (about 10 to 15 percent of the membership at that time according to Steffen, 2015; then winner Petry speaks even of those "ultimately over twenty percent" that left; see Petry, 2021, p. 151).

The party's turn to the PRR on the eve of the "refugee crisis" brought further electoral success, yet no internal harmony. Since 2015, conflicts have mainly revolved around strategy and the distribution of posts. Notably, Petry soon faced opposition against her plans to prepare the party for a coalition with the CDU and to keep a distance from the far-right Patriotische Europäer gegen die Islamisierung des Abendlandes (PEGIDA, Patriotic Europeans Against the Islamisation of the Occident) protestors (Weisskircher \& Berntzen, 2019, p. 121). As a result, she did not become the party's top candidate in the 2017 federal election. Only a day after the national vote, i.e., the AfD's biggest success, Petry resigned as co-spokesperson and left the party. However, her departure did not prevent further conflict. While many of those western neoliberals who had remained inside the party-including co-spokesperson Jörg Meuthenwere quick to adopt stark anti-immigrant rhetoric, they still clashed with members in the east. In contrast to Meuthen and others, many easterners felt little need for a "bourgeois" party image and had strong personal and organisational ties to far-right groups. This perspective was exemplified by Der Flügel (The Wing), an informal party group that "dissolved" in 2020, having faced scrutiny from the Federal Office for the Protection of the Constitution.

Internal struggles subsequently peaked: Meuthen successfully pushed for the revocation of key The Wing organiser Andreas Kalbitz's party membership on the grounds that he had failed to provide information on his extreme right activist past when joining the AfD. The executive committee's decision on Kalbitz's removal was remarkably close: seven to five, with one abstention. All supporters of Kalbitz's removal were politically based in western Germany or Berlin. However, this outcome was everything but a decisive victory for Meuthen, who continued to face sharp criticism from his opponents.

To some extent, the party's internal disputes still relate to policy conflicts. The party is divided over socioeconomic policies. While western German AfD politicians, in line with many of the party's founders, typically promote neoliberal policies, many easterners propose an expansion of the welfare state, at least for German citizens. The party's pension policy has long been a key bone of contention-with diverging proposals such as the expansion of private pension schemes or higher state pensions for German citizens, which have been met with harsh criticism from their respective opponents. Even after the AfD adopted its first comprehen- sive party manifesto in 2016, internal disagreement over many key issues remained. Most recently, the party was divided over how to respond to the Covid-19 pandemic and whether to cooperate with anti-lockdown protestors (Heinze \& Weisskircher, in press).

In sum, Alexander Gauland's well-known, if slightly unusual, comparison of the AfD to a gäriger Haufen ("fermenting heap") is a pointed description of the heterogeneity, or rather constant tensions, inside the party. The formal and informal organisation of the AfD reflects, not necessarily intentionally, the inclusion of a diversity of German far-right actors, which also contributes to internal disputes.

\section{The AfD's Adoption of Elements of a Mass Party-Type Organisation}

\subsection{A Considerable Degree of Formal and Informal Organisation}

While the AfD is clearly not a textbook example of a mass party, it has managed to adopt some elements of such an organisational model, i.e., the successful recruitment of a significant membership and a degree of rootedness in parts of society-especially so in eastern Germany. Unlike previous far-right parties, the AfD has quickly managed to build an organisation relying on a relatively large membership in all 16 federal states (Niedermayer, 2020 , p. 19). While it already had 17,687 members in its founding year, by 2019 it had almost twice as many $(34,751$; Niedermayer, 2020, p. 6). The party has about half as many members as the $\operatorname{FDP}(65,479)$ or Die Linke (The Left; 60,862), which have existed for much longer. In 2020, the number dropped for the first time-to about 32,000 members. AfD says that it terminated some memberships due to non-payment of fees. Moreover, internal disputes may also partially explain the decline in numbers ("Mitgliederschwund bei der AfD," 2021). Still, the AfD has been able to build a significant membership base, especially in the eastern states (see Figure 1), where citizens' ties to mainstream parties have been weak since German unification. Importantly, though, the population size of eastern Germany is substantially smaller than in the west. This is why, in absolute terms, the AfD recruits most of its members in the most populous states (see Figure 2), especially in North Rhine-Westphalia $(5,552)$, Bavaria $(5,094)$, and BadenWürttemberg $(4,836)$. In comparison, the absolute membership of AfD Thuringia-an electorally successful eastern branch particularly prominent for its radicalism and for leader Björn Höcke-is much smaller $(1,225)$. This fundamental asymmetry (broader appeal in the east but more absolute party members in the west) is crucial to understanding the internal power struggle within the party and its collective leadership (see below).

The AfD's relatively high degree of organisation is also reflected in its complex set of party organs at the national, regional, and local levels. The most 


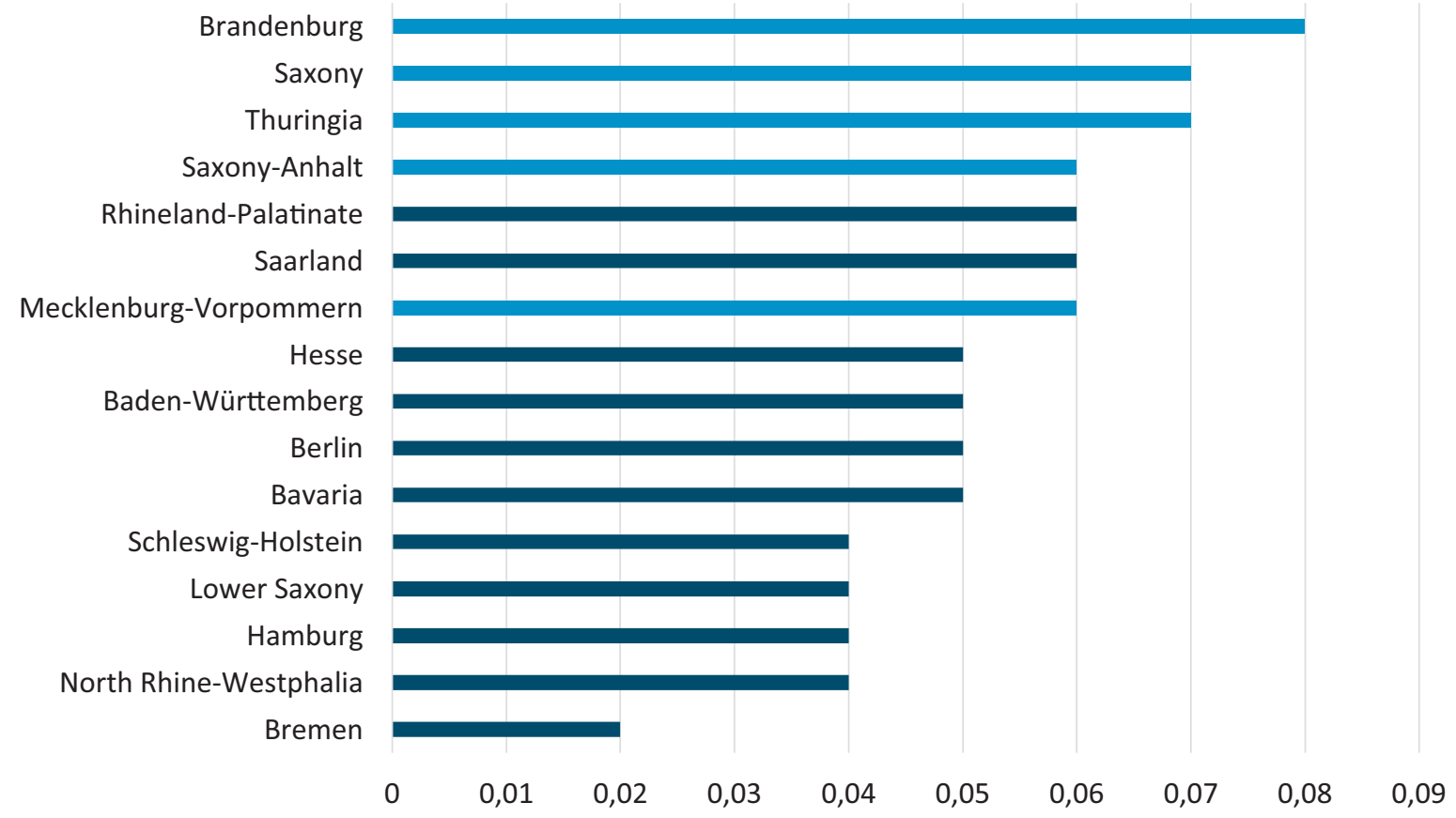

Figure 1. AfD recruitment capacity by federal states 2019. Notes: Recruitment capacity equals party members as a share of those eligible to join; light blue columns are eastern German states. Source: Based on data from Niedermayer (2020, pp. 19, 69).

important national party organs are the party conference (Bundesparteitag), the convention (Konvent), and the executive committee (Bundesvorstand). Formally, the highest organ is the party conference: It takes place at least once a year and is now usually made up of 600 delegates sent by the state branches and the members of the executive committee (until 2016, however, member and not delegate conferences were the typical format; see Section 4.2). The party conference decides on fundamental organisational and programmatic issues (e.g., manifesto and statutes). The convention can be interpreted as a "small" party conference: It consists of 50 delegates of the state branches and five executive committee members. It decides primarily on the

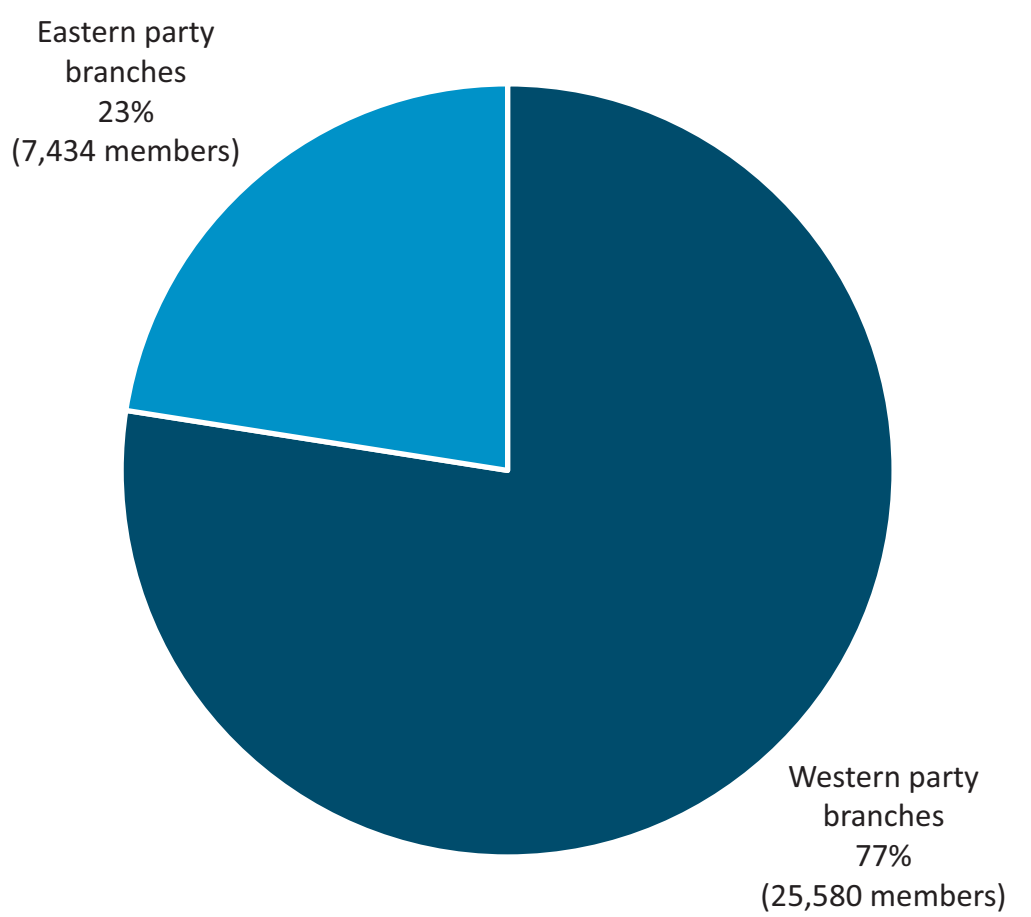

Figure 2. AfD membership by region. Note: Berlin (1,571 members) and members abroad (166) excluded. Source: Based on data from Niedermayer (2020, p. 19). 
use of state party funds, the budget, and financial planning, but also on the foundation of intra-party groups and the rules of procedure for party bodies and member decisions. The executive committee's formal tasks include implementing the decisions of the party conference and the convention. In practice, it plays an important role in matters related to policy, strategy, and personnel. It consists of two or three formally equally powerful spokespersons (Bundessprecher), three deputy spokespersons, the treasurer and his deputy, the secretary, and six other members. Its members are elected for two-year tenures by the party conference. Since 2017, the influence of the spokespersons-the party leadership-has not only been matched but often been overshadowed by the (dual) leadership of the Bundestag group (see Section 4.1).

Beyond its official organisation, the AfD has always consisted of several formal and informal groups, organising the interests of its diverse members and reflecting ideological divisions within the party. The first important example was Christen in der AfD (Christians in the AfD), founded in 2013. Its key aims were opposing abortion and equal marriage, but the group exerted only limited influence on the federal party (Jentsch, 2016). An early and key interest group of far-right forces inside the party was the Patriotic Platform, established in 2014. It was dissolved four years later when facing threat of observation from the Office for the Protection of the Constitution. The Wing suffered a similar fate: The informal group existed from 2015 to 2020, when the party executive demanded its "dissolution" to avoid scrutiny from the intelligence services. Despite these steps, the respective informal networks have continued to exist. In opposition to the growing strength of the wing, rather "moderate" groups were also established, such as the Alternative Mitte (Alternative Centre). By now, however, it has become dysfunctional due to its relatively small circle of remaining supporters.

\subsection{Recruitment and Mobilisation: A Movement-Party Strategy}

The AfD's significant membership points to its quite effective recruitment and mobilisation efforts for which it uses "classical" approaches such as local offices and events, information booths, regular mail, and online ads. Most interestingly, parts of the party have actively tried to expand its activist base by reaching out to conservative and far-right social movement players in an attempt to connect to organised protests from the right. Strong ties with, for example, the Civil Coalition of Beatrix von Storch, which advocates neoliberal economic and conservative family policies, have been crucial from the outset. However, it is the far-right wing of the AfD which has controversially pursued a more general strategic aim of cooperation with street protestors. In January 2017, AfD Thuringia chairman Höcke propagated "the path of a fundamental-oppositional movement-party [on the streets] and a fundamental-oppositional movementfaction [in parliament]":

And in order not to betray its historical mission, AfD has to remain a movement party; that is, it has to be present on the street again and again, and it has to be in close contact with friendly citizen movements. (Höcke, 2017)

In a similar vein, Gauland refers to the AfD as a "movement-party, which should cultivate contacts to certain protest groups" (as quoted in "Gauland will AfD," 2020).

However, the strategic establishment of links to far-right groups, first and foremost PEGIDA, have remained highly disputed within the party (Weisskircher \& Berntzen, 2019). In general, eastern German AfD branches were much more open to cooperation with PEGIDA than western ones-corresponding to the geographical distribution of far-right activism, which is more frequent in the east (Backes \& Kailitz, 2020). In 2016, several local politicians evaded the decision of the party's federal executive committee to ban cooperation with the Dresden-based protestors: They organised formally independent protest events that were held on the same day and at the same location as PEGIDA events. In March 2018, the party convention eventually reversed the decision, in line with the reality on the ground: With the decline of the "moderates" inside the party, cooperation with PEGIDA has become increasingly acceptable.

There have been many other examples of leading AfD figures strategically focusing on street politics. In 2015, Hans-Christoph Berndt founded Zukunft Heimat (Future Homeland) in Brandenburg. Later, Berndt managed to become a key AfD politician in the region. Prominent guest speakers at his protest events included Gauland and former member Kalbitz. Beyond anti-immigration protests, Stefan Möller, leading politician in Thuringia, even refers to the AfD as the "legislative arm of the anti-wind-energy movement" (Radau, 2019). Reflecting the party's stark opposition to policies on global warming (Otteni \& Weisskircher, 2021), some AfD politicians have tried to cooperate with protest groups that mobilise against the construction of wind turbines. Many AfD politicians have also been supportive of protests against the Covid-19 pandemic policies, organising their own demonstrations during "lockdowns" or cooperating with Querdenken (lateral thinking) protestors, for example, by serving as guest speakers - to the strong dismay of AfD politicians such as Meuthen (Heinze \& Weisskircher, in press). In addition, the party's youth organisation Junge Alternative (JA) has strong links with the far-right subcultural milieu, including student fraternities (Herkenhoff, 2016). In 2018, the German Office for the Protection of the Constitution and some of its regional branches started observing the JA because of its ties to the Identitarian Movement. In November 2018, the Lower-Saxon branch of the JA, the first one 
to be observed by the German intelligence service, was even dissolved by the federal JA. Moreover, individuals such as Hans-Thomas Tillschneider, a key figure of the Patriotic Platform, have also had close ties to the far-right Identitarians.

Given its relations to the far-right scene, it is unsurprising that the AfD attracted some undesired formal members, i.e., right-wing extremists who harmed the party's public image. As a response to both public pressure and internal pressure by "moderates," the party has constantly added ever-more groups to its "list of incompatible organisations" (Unvereinbarkeitsliste). By December 2020, this list consisted of twelve pages and included not only the category of "right-wing extremism," but also that of "foreign extremism," "left-wing extremism," "Islamism/Islamist terrorism," and "scientology" (it is quite unlikely that members of the latter four groups have actually applied to AfD). Among the extreme right groups listed are the Identitarian Movement, the NPD, some Bavarian PEGIDA spinoffs, skinhead groups, and white supremacists. The recruitment of new AfD members and activists is therefore strongly constrained by the organisational past of some of its sympathisers - and has even caused the fall of established AfD politicians, such as Kalbitz. Sometimes, however, "creative" solutions secure cooperation, especially through the hiring of former members of "incompatible organisations" as employees of legislative deputies - without them becoming formal members.

\subsection{The Role of the Internet for Mobilisation}

To recruit popular support, the online sphere has always been important to the AfD. As far back as 2014 and 2015, the party's Facebook activity substantially overshadowed those of established political parties, peaking in autumn 2015, at the height of the "refugee crisis" (Schelter et al., 2016). The party was quick to adopt various social media platforms, and its accounts have often attracted more followers than the profiles of other Bundestag parties (Medina Serrano et al., 2019). Ahead of the federal election 2017, AfD candidates significantly increased their social media activity, posting mainly negative content with a particular focus on immigration (Melcher, 2019). Importantly, the AfD also takes advantage of YouTube by promoting Bundestag speeches of its MPs (e.g., via its own channel, AfD TV).

Still, despite the party's focus on the online sphere, none of its politicians is as prominent as PRR leaders such as Matteo Salvini or Heinz-Christian Strache, not to mention Donald Trump. AfD's most prominent face, long-term chairperson Gauland, born in 1941, has been known for his lack of interest in and refusal to adopt social media. Nevertheless, many AfD politicians make active use of their personal social media profiles. This includes Höcke, who, like many of his fellows, increasingly uses Telegram, criticising "censorship" on his popular Facebook account.
Importantly, the AfD also cooperates with "alternative media" platforms, which have become an increasingly relevant instrument of far-right mobilisation (Rone, 2021). Such platforms have flourished in the Germanspeaking online sphere, with Politically Incorrect News as the main example (Weisskircher, 2020a). Some AfD politicians contribute to this and other platforms as authors. Moreover, the AfD has placed advertisements on such sites. In May 2019, its Bundestag group even invited individuals in charge of these platforms to a "first conference on free media."

\subsection{Reasons for the Adoption of Elements of a Mass Party-Type Organisation}

The AfD has managed to build a relatively dense net of branches across Germany while also reaching out beyond its formal party organisation in an attempt to become the key actor of the self-proclaimed Mosaikrechte (mosaic right), i.e., the diverse set of far-right players in Germany. Apart from recruitment and rootedness, however, the AfD is unable to fulfil other tasks usually associated with the mass-party model, including the organisation of several activities for members, shaping their identities, and providing services to them "from the cradle to the grave." Its efforts to build membership and develop strong ties to other actors can be attributed to factors specific to the German political system on the one hand and to the role of the AfD on the other.

First, the AfD's complex set of party organs corresponds to the requirements of German law. According to the Basic Law (Article 21(1)), the parties' internal organisation must comply with democratic principles. The party law specifies these requirements, such as that the supreme decision-making body for central policy and personnel decisions is the general meeting of members or representatives (party conference) and that the executive committee must consist of at least three members. The electoral law requires a democratic nomination of candidates (party lists). Moreover, with its frequent state and municipal elections, German federalism provides strong incentives for the AfD to build structures across the country: Successful electoral showings provide offices and public funding. In addition, if a party does not participate in either a federal or state election for six years, it loses its legal status as a party.

Second, factors specific to the AfD's role in the political system explain why many of its politicians have reached out beyond the formal party organisation. While the AfD was soon excluded by established parties (Heinze, 2020a) and left-wing and liberal civil society actors (Schroeder et al., in press), parts of the party have tried to expand their base by pursuing a 'movement-party' approach. There are several reasons for such a strategy. First, strong connections to civil society contribute to the electoral stability of political parties (Martin et al., 2020). Second, attempts to 
reach out beyond the electoral arena correspond to the metapolitics-strategies of 'new right' ideology, which emphasises the importance of being embedded into broader society to be able to achieve lasting political change. This ideology arose from French far-right intellectuals' adoption of the Marxist philosopher Antonio Gramsci, which was subsequently employed by their German counterparts who also wanted to promote efforts to achieve political influence beyond electoral politics and state institutions (Ravndal, 2021). Third, and not to be underestimated, cooperation with activists is also important for individual AfD politicians trying to increase their personal standing inside the party. In addition, the AfD's focus on online activism and its embrace of "alternative media" can also be attributed to the difficult relationship between PRR parties and the mainstream media (de Jonge, 2021).

\section{Decision-Making and Internal Democracy Within the AfD}

\subsection{Decentralisation of Power}

Unlike other PRR parties, so far the AfD has relied on collective leadership. Despite attempts at centralisation, power within the party has never been concentrated in one (charismatic) leader alone but has been divided among different top politicians. These play a crucial role in the party's policy and strategic decisions. Again, the practice of collective leadership reflects great internal differences.

Most importantly, following the AfD's entry into the Bundestag in 2017, the party opted for a dual leadership of its parliamentary group. From 2017 to 2021, its leaders were Alexander Gauland and Alice Weidel, the two AfD top candidates for the election. After the 2021 election, the top candidates-Tino Chrupalla and Weidelagain became leaders of the Bundestag group. There, they have an important leadership and steering function, organise internal majorities, ensure the group's cohesion, prepare meetings (including the selection of speak- ers for Bundestag debates), and represent their group in public (including giving key speeches in the Bundestag). In practice, the leaders of the Bundestag group are the most visible AfD politicians in charge of everyday affairs. However, Gauland and Weidel sometimes struggled to control their own parliamentary group, as underlined by strong internal criticism of the group's organisation. Correspondingly, AfD MPs are also those that most frequently deviate from the party line in their voting behaviour (Kuchlmayr \& Pauly, 2019).

The second power centre is the executive committee, i.e., the leadership of the national party. As stipulated in the statute, it has always been led by two or three spokespersons. A January 2015 statute change to reduce the number of spokespersons to one from December 2015 onwards, driven by Lucke, did not survive his downfall half a year before the scheduled date. Also, until 2021, putting aside the exceptional circumstances of Gauland's reign as spokesperson (2017-2019), AfD spokespersons have been different from its Bundestag leadership. So far, speaker positions have changed hands several times, underlining the AfD's lack of stable leadership (see Table 1). None of the initial spokespersons is still a member of the party. Current spokespersons are Tino Chrupalla and the outgoing Jörg Meuthen. Meuthen, the longest-lasting chairperson, is a Member of the European Parliament and, therefore, often not at the forefront of the German political scene. Chrupalla was only narrowly elected at the 2019 party conference. Unlike the neoliberal Meuthen, based in the west, the Saxon Chrupalla was supported by The Wing and by Gauland. The federal executive committee is quite heterogeneous: Its decision to remove Kalbitz was narrow and involved hostile debates with Meuthen and Chrupalla on opposite sides.

Subnationally, party and parliamentary leadership focus primarily on the respective federal state, but some actors have a significant informal impact beyond that. For example, Thuringian spokesman and parliamentary co-leader Höcke has influenced the policy and strategic direction of the entire AfD. Together with André

Table 1. Overview of the previous federal spokespersons of the AfD.

\begin{tabular}{llllll}
\hline \multirow{2}{*}{ Years in office } & Name & Gender & $\begin{array}{l}\text { Year and region } \\
\text { of birth }\end{array}$ & Occupation & Former political affiliation \\
\hline $2013-2015$ & Bernd Lucke & Male & 1962, West & Professor of economics & CDU \\
$2013-2015$ & Konrad Adam & Male & 1942, West & Journalist & CDU \\
$2013-2017$ & Frauke Petry & Female & 1975, East & Entrepreneur & None \\
Since 2015 & Jörg Meuthen & Male & 1961, West & Professor of economics & $\begin{array}{l}\text { Short-time member } \\
\text { of CDU youth }\end{array}$ \\
& Alexander Gauland & Male & 1941, East & $\begin{array}{l}\text { Top-level bureaucrat and } \\
\text { newspaper editor }\end{array}$ & CDU \\
Since 2019 & Tino Chrupalla & Male & 1975, East & $\begin{array}{l}\text { House painter and } \\
\text { entrepreneur }\end{array}$ & $\begin{array}{l}\text { Short-time member } \\
\text { of CDU youth }\end{array}$
\end{tabular}


Poggenburg, then chairman in Saxony-Anhalt, he initiated the Erfurter Resolution in 2015, which was supported by 18 other initial signers (Höcke \& Poggenburg, 2015). Höcke's influence is based on his strong networking of the mainly eastern far-right inside the party, his focus on party-movement interactions, large media attention for provocative and extremist public statements, and significant electoral success in Thuringia.

The offices of parliamentary and party spokesperson at the state level are usually separated-only in a few states is decision-making more concentrated. Depending on the statutes of the respective AfD state branches, regulations for state executive committees vary. Some statutes call for exactly one chairperson (or "spokesperson"), others for "at least one," "one or two," or "up to three." In practice, most AfD state associations are led by one person. Dual leadership in state legislatures is also less common.

\subsection{Internal Democracy}

The AfD has always tried to present itself as a party cherishing internal democracy, reflecting the party's anti-elitist ideology of representing the interests of "the people" against those of the "corrupt elites" (Mudde, 2007), in line with other parties typically labelled as "populist" (Caramani, 2017; Vittori, 2020). In its 2013 statute, for example, the AfD described itself as the only real "alternative" to the non-transparent, remote and undemocratic "old parties" (Alternative für Deutschland, 2013 , p. 1). Some observers compare party members' desire for widespread participation to the anti-elitist origins of the German Die Grünen (The Greens; Bender, 2017). In fact, the AfD introduced various instruments of intra-party participation early on, such as member party conferences and internal referenda. However, the practice of intra-party democracy has always remained controversial, as we illustrate in the following.

Importantly, party conferences, as the AfD's formally highest organ, were initially held as member party conferences (Mitgliederparteitage). The first statute required them and only allowed for optional delegate party conferences (Delegiertenparteitage) after acquiring 10,000 members. Consequently, all members were initially allowed to participate in, discuss, and vote on central party issues. Over time, the AfD moved away from this practice and increasingly held delegate party conferences (see Table 2). Organisational and strategic reasons were decisive. For instance, in 2014, it took hours until members passed the conference's agenda alone. The large meetings were also costly, putting a strain on the party's budget (Petry, 2021, pp. 130, 132). After Petry toppled Lucke at the party conference in Essen (with about 3,000 members present), the practice of member party conferences was finally changed. The November 2015 party statute enshrined delegate party conferences as the default model. After that, only one more member party conference was held at the national level. In general, this development cannot only be seen as a concentration of power but also as a typical professionalisation process (Bolleyer \& Bytzek, 2017; Tronconi, 2018) in the context of a surging membership. Still, delegate conferences sometimes vote against the will of the party leadership, even on crucial matters: In April 2021, the party conference decided to include the call for an end of Germany's EU membership (Dexit) in its electoral manifesto.

Further evidence points to the relative inclusiveness of AfD's party organisation: Of all parties entering the Bundestag in 2017, it was the AfD that involved the highest share of members in the selection of candidates for the election. The AfD also had the strongest internal competition: Almost every place was contested. While still only 42 percent of its members were very satisfied with the opportunities for participation, this was more than for any other parties and about twice as high as for CDU and SPD (all data from Höhne, 2021).

Moreover, the party statute provides for the opportunity of binding member decisions (Mitgliederentscheide) and non-binding member surveys (Mitgliederbefragungen). Member decisions may concern policy and organisational questions that are not the responsibility of the

Table 2. Overview of the federal party conferences.

\begin{tabular}{lllll}
\hline No. & Date & Location & Central topics & Participants \\
\hline 1 & April 2013 & Berlin & Foundation, party statute, manifesto (Bundestag election) & Members \\
2 & March 2014 & Erfurt & Manifesto (EP election) & Members \\
3 & Jan.-February 2015 & Bremen & New statute & Members \\
4 & July 2015 & Essen & Election of executive committee & Members \\
5 & November 2015 & Hannover & Change of statute & Delegates \\
6 & April-May 2016 & Stuttgart & Party manifesto & Members \\
7 & April 2017 & Cologne & Manifesto (Bundestag election) & Delegates \\
8 & December 2017 & Hannover & Election of executive committee & Delegates \\
9 & June-July 2018 & Augsburg & Vote on political foundation & Delegates \\
10 & Nov.-December 2019 & Braunschweig & Election of executive committee & Delegates \\
11 & November 2020 & Kalkar & Pension concept & Delegates \\
12 & April 2021 & Dresden & Manifesto (Bundestag election) & Delegates \\
\hline
\end{tabular}


federal party conference. Depending on the issue, most decisions require a simple majority for approval, with the threshold being at least one-fifth of all members in favour. Voting is by postal vote or the ballot box. In contrast, member surveys can also cover AfD's manifesto, statutes, and top candidates. Voting takes place online. According to the party statute, members must be involved in the development of manifestos through member surveys. However, their results are merely recommendations to the federal programme commission (Bundesprogrammkommission). Both member decisions and member surveys can be requested by the federal executive committee, the federal conference, the federal convention, three state executive committees, 25 district executive committees, or three percent of all AfD members.

Despite all these possibilities for top-down initiation and the low threshold for bottom-up initiation, neither instrument is part of the party's daily routine. In January 2020, the first and only member decision was initiated from the bottom-up. It demanded that the next party conference be held as a member party conference, i.e., in theory, with all $(>30,000)$ members. The federal executive committee opposed this initiative for organisational and financial reasons. In the end, despite a clear majority for the proposal, the 20 percent quorum was not reached. Still, it revealed the ongoing intra-party conflict over the representativeness of delegate party conferences. The initiator of the member decision, Hansjörg Müller (MP in the Bundestag and deputy chairman of AfD Bavaria), notably criticised a "tendency towards oligarchisation," stating that:

To be fully honest: also we distanced ourselves already too much from grassroots democratic principles. We could have spared ourselves the troubles of building a party and instead have entered an Altpartei [old party] right away. (Müller, 2019)

The non-binding member survey has been used more often, e.g., for the establishment of the first party manifesto in 2016, as well as the manifestos for the European Parliament elections in 2014 and 2019, and the 2017 Bundestag election. Some results have been implemented, others not at all, whilst yet others have been intensively discussed and altered at party conferences. Some questions have been framed in a highly biased way, already pointing to the desired responses (e.g., on state rent control, described as an instance of "planned economy").

An important recent membership survey shows how intra-party democracy and leadership struggles may interact: Ahead of the 2021 federal elections, 87 percent opted for choosing the top candidates through another membership survey and not at a party conference (about a quarter of all members participated). This result was not binding. Yet, at the following party conference, a narrow majority of delegates then also formally decided on such a membership vote, referring to the need to respect the outcome of the member survey. Beyond the will of the party's rank-and-file, however, it was cochairman Meuthen who campaigned for members to decide about the top candidates - in a vain attempt to weaken the chances of his archenemy Weidel becoming one of these frontrunners.

\section{Conclusion}

Our article has comprehensively analysed AfD's party organisation, especially its adoption of elements of a mass party and its decentralised decision-making. The AfD is not a mass party, but, especially in eastern Germany, it has managed to recruit a significant membership and has achieved a degree of rootedness in parts of society. However, the party is not in a position to provide activities and services for its members or to shape their identities on an everyday basis. Importantly, the party clearly deviates from the "classic" model of PRR party organisation, i.e., the combination of "charismatic" leadership and centralisation of power. Instead, so far it has shared power within collective leadership structures, especially at the federal level. Moreover, the party provides for instruments of internal democracy, i.e., binding and non-binding referenda. Party conferences have often included not only delegates but all members-especially at the subnational level. When deciding on electoral lists, party members have been strongly involved. Finally, parts of the party have also actively reached out to mainly far-right social movements, propagating a "party-movement" strategy and creating strong ties to non-party actors. To some extent, these dimensions of the AfD's formal and informal organisation are reminiscent of Green and left-wing parties and less of PRR parties.

However, as with other parties, the AfD's lived organisation departs from what is written in its statutes with actual decision-making being more concentrated than formal rules would suggest. Most obviously, directdemocratic instruments have not been part of the party's daily routine. In practice, the Bundestag co-leadership and the federal executive committee, which includes representatives of the party's strong internal factions, are driving forces inside the party. Also, the controversy surrounding the organisation of delegate party conferences indicates that many top party officials prefer not to hold inclusive member party conferences. Still, the party rank-and-file has regularly influenced the party's direction, sometimes against the will of (parts of) the party leadership.

Consequently, collective leadership and decentralisation also reflect the substantial internal conflict within the AfD. At the same time, these organisational features have failed to bring about appeasement. Instead, the frequently visible internal turmoil serves as the best evidence for the lack of effective leadership at the top of the AfD. To be sure, this has not prevented the party from 
establishing itself in the Bundestag, given the substantial demand-side changes in German politics over the course of the "refugee crisis" (Mader \& Schoen, 2018). Effective internal management is not key in understanding the AfD's electoral success. Whether strong leadership and centralisation would have increased the party's appeal even more must remain an exercise in counterfactual history. So far, calls for a centralisation of power, such as relying only on one chairperson, have not gained traction yet, but are not off the table either-several leading and quite different AfD politicians such as Lucke, Petry, or Höcke have at times supported such a step. The future will show to what extent the "iron law of oligarchy" (Michels, 1915/1962) also applies to the AfD.

Our analysis has shown that PRR parties are able to build strong organisations with opportunities for intraparty participation. Future research should examine the extent to which PRR claims that they have a beneficial impact on the quality of democracy stand up to scrutiny, how decision-making is perceived by members and non-members, and whether support for intra-party democracy is instrumental or principled. Such a perspective may increase our knowledge about the relationship between the PRR and democratic participation. Moreover, comparative research needs to investigate how and to what extent PRR parties strategically pursue cooperation with non-party actors and whether this helps them become embedded into society beyond the parliamentary arena. This could also help us understand why the PRR is here to stay-both from an ideological and an organisational perspective.

\section{Acknowledgments}

We thank Uwe Backes, three anonymous reviewers, and the academic editors, Daniele Albertazzi and Stijn van Kessel, for their valuable feedback.

\section{Conflict of Interests}

The authors declare no conflict of interest.

\section{References}

Albertazzi, D., \& van Kessel, S. (2021). Right-wing populist party organisation across Europe: The survival of the mass party? Introduction to the thematic issue. Politics and Governance, 9(4), 224-227.

Alternative für Deutschland. (2013, April 14). Bundessatzung der Alternative für Deutschland [Federal Statute of the Alternative for Germany]. https:// www.politicalpartydb.org/wp-content/uploads/ Statutes/Germany/Germany_AfD_2013.pdf

Art, D. (2011). Inside the radical right: The development of anti-immigrant parties in Western Europe. Cambridge University Press.

Arzheimer, K. (2015). The AfD: Finally a successful rightwing populist Eurosceptic party for Germany? West
European Politics, 38(3), 535-556.

Arzheimer, K. (2019). "Don't mention the war!" How populist right-wing radicalism became (almost) normal in Germany. Journal of Common Market Studies, 57(S1), 90-102.

Backes, U., \& Kailitz, S. (Eds.). (2020). Sachsen-eine Hochburg des Rechtsextremismus? [Saxony-a stronghold of right-wing extremism?]. Vandenhoeck \& Ruprecht.

Backes, U., \& Mudde, C. (2000). Germany. Extremism without successful parties. Parliamentary Affairs, 53(3), 457-468.

Bender, J. (2017). Was will die AfD? Eine Partei verändert Deutschland [What does the AfD want? A party changes Germany]. Pantheon.

Bennett, A., \& Elman, C. (2006). Qualitative research: Recent developments in case study methods. Annual Review of Political Science, 9, 455-476.

Berbuir, N., Lewandowsky, M., \& Siri, J. (2015). The AfD and its sympathisers: Finally a right-wing populist movement in Germany? German Politics, 24(2), 154-178.

Betz, H. (1998). Introduction. In H. Betz \& S. Immerfall (Eds.), The new politics of the right: Neo populist parties and movements in established democracies (pp. 1-10). St. Martin's Press.

Biebricher, T. (2018). Geistig-moralische Wende. Die Erschöpfung des deutschen Konservatismus [Spiritual-moral turn. The exhaustion of German conservatism]. Matthes \& Seitz Berlin.

Bolleyer, N., \& Bytzek, E. (2017). New party performance after breakthrough: Party origin, building and leadership. Party Politics, 23(6), 772-782.

Caiani, M., \& Císař, O. (Eds.). (2019). Radical right movement parties in Europe. Routledge.

Caramani, D. (2017). Will vs. reason: The populist and technocratic forms of political representation and their critique to party government. American Political Science Review, 111(1), 54-67.

Carter, E. (2005). The extreme right in Western Europe: Success or failure? Manchester University Press.

de Jonge, L. (2021). The success and failure of right-wing populist parties in the Benelux countries. Routledge.

Decker, F. (2000). Über das Scheitern des neuen Rechtspopulismus in Deutschland: Republikaner, StattPartei und der Bund Freier Bürger [On the failure of the new right-wing populism in Germany: Republicans, Statt Party and the Free Citizens League]. Österreichische Zeitschrift für Politikwissenschaft, 29(2), 237-256.

della Porta, D., Fernández, J., Kouki, H., \& Mosca, L. (2017). Movement parties against austerity. Polity Press.

Dinas, E., Georgiadou, V., Konstantinidis, I., \& Rori, L. (2016). From dusk to dawn: Local party organisation and party success of right-wing extremism. Party Politics, 22(1), 80-92.

Gauland will AfD als „Bewegungspartei” erhalten 
[Gauland wants to maintain AfD as a „movementparty“]. (2020, December 20). Der Tagesspiegel. https://www.tagesspiegel.de/politik/streitmit-parteichef-meuthen-gauland-will-afd-alsbewegungspartei-erhalten/26736652.html

Häusler, A. (Ed.). (2016). Die Alternative für Deutschland: Programmatik, Entwicklung und politische Verortung [The Alternative for Germany: Programme, development, and political direction]. Springer.

Heinisch, R., \& Mazzoleni, O. (2016). Comparing populist organisations. In R. Heinisch \& O. Mazzoleni (Eds.), Understanding populist party organisation. The radical right in Western Europe (pp. 221-246). Palgrave.

Heinze, A. S. (2020a). Strategien gegen Rechtspopulismus? Der Umgang mit der AfD in Landesparlamenten [Strategies against right-wing populism? Dealing with the AfD in state parliaments]. Nomos.

Heinze, A. S. (2020b). Zum schwierigen Umgang mit der AfD in den Parlamenten: Arbeitsweise, Reaktionen, Effekte [Dealing with AfD in parliament: Legislative behaviour, responses, effects]. Zeitschrift für Politikwissenschaft, 31(1), 133-150.

Heinze, A. S., \& Weisskircher, M. (in press). How political parties respond to pariah street protest: The case of anti-corona mobilization in Germany. German Politics.

Herkenhoff, A. (2016). Rechter Nachwuchs für die AfDDie Junge Alternative (JA) [Right-wing offspring for the AfD-The Young Alternative]. In A. Häusler (Ed.), Die Alternative für Deutschland: Programmatik, Entwicklung und politische Verortung [The Alternative for Germany: Programme, development and political direction] (pp. 201-217). Springer.

Höcke, B. (2017, January 19). "Gemütszustand eines total besiegten Volkes." Höcke-Rede im Wortlaut ["Emotional state of a totally defeated people." Speech transcript]. Der Tagesspiegel. https://www. tagesspiegel.de/politik/hoecke-rede-imwortlaut-gemuetszustand-eines-total-besiegtenvolkes/19273518-all.html

Höcke, B., \& Poggenburg, A. (2015). Erfurter Resolution. Der Flügel. https://gei-ge.de/node/15712704 0041474/erfurterresolution.pdf

Höhne, B. (2021). How democracy works within a populist party: Candidate selection in the Alternative for Germany. Government and Opposition. Advance online publication. https://doi.org/10.1017/ gov.2021.33

Jentsch, U. (2016). Die „Lebensschutz"-Bewegung und die AfD. Nur ein Teil der Bewegung ergreift Partei [The "pro-life" movement and the AfD. Only a part of the movement takes sides]. In A. Häusler (Ed.), Die Alternative für Deutschland: Programmatik, Entwicklung und politische Verortung [The Alternative for Germany: Programme, development and political positioning] (pp. 99-107). Springer.

Kitschelt, H. (2006). Movement parties. In R. Katz \& W. Crotty (Eds.), Handbook of party politics (pp.
278-290). SAGE.

Kuchlmayr, F., \& Pauly, M. (2019, August 4). Abweichler im Bundestag. Parlamentarischer Ungehorsam [Dissenters in the Bundestag. Parliamentary disobedience]. Spiegel. https://www.spiegel.de/politik/ deutschland/bundestag-diese-abgeordnetenstimmen-oft-gegen-die-eigene-fraktion-a1279893.html

Mader, M., \& Schoen, H. (2018). The European refugee crisis, party competition, and voters' responses in Germany. West European Politics, 42(1), 67-90.

Martin, N., de Lange, S., \& van der Brug, W. (2020). Holding on to voters in volatile times: Bonding voters through party links with civil society. Party Politics. Advance online publication. https://doi.org/ 10.1177\%2F1354068820980304

Medina Serrano, J. C., Shahrezaye, M., Papakyriakopoulos, O., \& Hegelich, S. (2019). The rise of Germany's AfD: A social media analysis [Paper presentation]. 10th International Conference on Social Media and Society, Canada.

Melcher, R. (2019). Alternativer Wahlkampf? Social Media und individuelle Kandidat*innenkampagnen [Alternative Election Campaign? Social media and individual candidate campaigns]. In W. Schroeder \& B. Wessels (Eds.), Smarte Spalter. Die AfD zwischen Bewegung und Parlament [Smart dividers. The AfD between movement and parliament] (pp. 203-225). Dietz.

Michels, R. (1962). Political parties: A sociological study of the oligarchical tendencies of modern democracy. Dover. (Original work published 1915)

Mitgliederschwund bei der AfD [AfD membership decline]. (2021, January 1). Tagesschau. https:// www.tagesschau.de/inland/afd-parteimitgliederrueckgang-101.html

Mudde, C. (2007). Populist radical right parties in Europe. Cambridge University Press.

Müller, H. (2019). Für Mitgliederparteitage spricht [What speaks in favour of member party conferences]. Mitgliederparteitag.de. https://www. mitgliederparteitag.de/was-spricht-dafuer

Niedermayer, O. (2020). Parteimitglieder in Deutschland: Version 2020 [Party members in Germany: Version 2020] (Workbooks from the Otto Stammer Center No. 31). Freie Universität Berlin.

Otteni, C., \& Weisskircher, M. (2021). Global warming and polarization. Wind turbines and the electoral success of the greens and the populist radical right. European Journal of Political Research. Advance online publication. https://doi.org/10.1111/1475-6765. 12487

Petry, F. (2021). Requiem für die AfD [Requiem for the AfD]. Stadtluft.

Pirro, A., \& Castelli Gattinara, P. (2018). Movement parties of the far right: The organization and strategies of nativist collective actors. Mobilisation, 23(3), 367-383. 
Radau, L. (2019, October 25). Wo die AfD gegen Windmühlen kämpft [Where the AfD tilts at windmills]. Die Zeit. https://www.zeit.de/politik/deutschland/ 2019-10/windkraft-thueringen-wahlkampf-afdbuergerinitiative

Ravndal, J. (2021). From bombs to books, and back again? Mapping strategies of right-wing revolutionary resistance. Studies in Conflict \& Terrorism. Advance online publication. https://doi.org/ 10.1080/1057610X.2021.1907897

Rone, J. (2021). Far right alternative news media as 'indignation mobilisation mechanisms': How the far right opposed the global compact for migration. Information, Communication \& Society. Advance online publication. https://doi.org/10.1080/1369118X.2020. 1864001

Rüdig, W., \& Sajuria, J. (2020). Green party members and grass-roots democracy: A comparative analysis. Party Politics, 26(1), 21-31.

Sanches, E. R., Lisi, M., Razzuoli, I., \& Santo, P. (2018). Intra-party democracy from members' viewpoint: The case of left-wing parties in Portugal. Acta Politica, 53, 391-408.

Scarrow, S., Webb, P., \& Poguntke, T. (2017). Organising political parties: Representation, participation, and power. Oxford University Press.

Schelter, S., Biessmann, F., Zobel, M., \& Teneva, N. (2016). Structural patterns in the rise of Germany's new right on Facebook [Paper presentation]. IEEE 16th International Conference on Data Mining Workshops (ICDMW), Spain.

Schroeder, W., Greef, S., Ten Elsen, J., \& Heller, L. (in press). Interventions by the populist radical right in German civil society and the search for counterstrategies. German Politics.

Schroeder, W., \& Wessels, B. (Eds.). (2019). Smarte Spalter. Die AfD zwischen Bewegung und Parlament [Smart dividers. The AfD between movement and parliament]. Dietz.

Steffen, T. (2015, July 10). Petry spricht von Sabotage [Petry speaks about sabotage]. Die Zeit. https://www.zeit.de/politik/deutschland/2015-07/ frauke-petry-bernd-lucke-afd-austritte

Tronconi, F. (2018). The Italian five star movement during the crisis: Towards normalisation? South European Society and Politics, 23(1), 163-180.

Vittori, D. (2020). The impact of populism on party organisation? A study of four Southern European 'populist' parties. European Politics and Society, 21(1), 53-71.

Weisskircher, M. (2020a). Neue Wahrheiten von rechts außen? Alternative Nachrichten und der „Rechtspopulismus" in Deutschland [New truths from the far right? Alternative news and "right-wing populism" in Germany]. Forschungsjournal Soziale Bewegungen, 33(2), 474-490.

Weisskircher, M. (2020b). The strength of far-right AfD in Eastern Germany: The east-west divide and the multiple causes behind "populism." The Political Quarterly, 91(3), 614-622.

Weisskircher, M., \& Berntzen, L. (2019). Remaining on the streets: Anti-Islamic PEGIDA mobilization and its relationship to far right party politics. In M. Caiani \& O. Císař (Eds.), Radical right movement parties in Europe (pp. 114-130). Routledge.

\section{About the Authors}

Anna-Sophie Heinze is a political scientist at the Trier Institute for Democracy and Party Research (TIDUP), University of Trier. In 2019, she defended her PhD thesis at the Friedrich Schiller University, Jena. Her research focuses on political parties, democracy, populism, and the far right. She is the author of Strategien gegen Rechtspopulismus? Der Umgang mit der AfD in Landesparlamenten and has published in journals such as West European Politics and Zeitschrift für Politikwissenschaft.

Manès Weisskircher is a political scientist at the Department of Sociology and Human Geography and the Center for Research on Extremism (C-REX), University of Oslo. In 2019, he defended his PhD thesis at the European University Institute. His research interests are social movements, political parties, democracy, and the far right. He has published in journals such as European Journal of Political Research, Political Studies, Government and Opposition, Social Movement Studies, The Political Quarterly, and Sociological Perspectives. 